IJIF

9,2

\section{0}

Received 7 August 2017 Revised 25 August 2017 31 August 2017

Accepted 1 September 2017

\title{
Contra trading in Bursa Malaysia Securities Berhad: a Sharī'ah and legal appraisal
}

\author{
Noor Suhaida Kasri and Burhanuddin Lukman \\ Research Affairs Department, International Shari'ah Research Academy for \\ Islamic Finance (ISRA), Kuala Lumpur, Malaysia
}

\begin{abstract}
Purpose - The purpose of this paper is to analyze the practice of contra trading in Bursa Malaysia Securities Berhad. Through a critical examination of the practice, it aims to discuss the issues from the angles of Shari' ah and Malaysian common law.

Design/methodology/approach - The paper uses a qualitative research methodology. The information on the practice of contra trading is obtained through the Bursa Malaysia Securities Berhad's website and literature as well as series of meetings and discussions held with Bursa Malaysia Securities Berhad. In comprehending and dissecting the Sharī'ah and legal issues, classical along with contemporary Sharīah literature including local and international Shar'`ah advisory bodies' resolutions and standards have been referred to. The Shari'ah analysis of these issues is further supported by reference to the statute and by-laws of Bursa Malaysia Securities Berhad as well as other related legal literature.

Findings - This paper finds that contra trading involves a real sale and purchase of shares; the shares are not taken into the possession of the contra trader, neither physically nor constructively; the liability of shares is not transferred to the contra trader; though the practice of profiting in contra trading may contradict the prohibition on profiting without bearing liability, the permissibility of contra trading could still be argued from the contextual approach of public interest (mașlahah) and needs (häjah); and contra trading is not gambling.
\end{abstract}

Research limitations/implications - This paper is limited in its analysis to only Sharīah and legal perspectives. It does not cover a thorough empirical and quantitative investigation that would measure the extent of the public needs for contra trading and the real benefits that contra trading brings about to the society in the long run. Such studies will further demonstrate whether contra trading deserves a relaxation from the strict Shari' ah ruling thus affirming the issue of permissibility of contra trading. Moving forward, this paper recommends ways to address the predicaments faced in the contra trading practices as well important research areas that could be taken up in future.

Originality/value - This paper provides an in-depth investigation of the practice of contra trading at the Bursa Malaysia Securities Berhad from the angles of Shari' ah and common law.

Keywords Legal, broker, exchange, contra trading, shares

Paper type Research paper

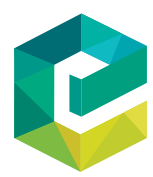

\section{Introduction}

Contra trading refers to an activity that allows a buyer to contra or offset its obligation to purchase shares with its broker before the settlement/maturity of the contract. The benefit of

ISRA International Journal of Islamic Finance Vol. 9 No. 2,2017 pp. $200-204$

(C) Noor Suhaida Kasri and Burhanuddin Lukman. Published in the ISRA International Journal of Islamic Finance. Published by Emerald Publishing Limited. This article is published under the Creative Commons Attribution (CC BY 4.0) licence. Anyone may reproduce, distribute, translate and create derivative works of this article (for both commercial and non-commercial purposes), subject to full attribution to the original publication and authors. The full terms of this licence may be seen at http://creativecommons.org/licences/by/4.0/legalcode 
contra is that it enables the buyer to exit the contract earlier. The end result of contra is the netting off between the amount the broker has to pay to the original seller for the price of the shares and the amount the broker receives from the new buyer for the price of the shares.

Although contra trading is claimed to facilitate the efficiency and liquidity of the market, the manner in which it is being carried out attracts Shari'ah scrutiny. The need to investigate the compliancy of contra trading practices is timely as at present the Shari ${ }^{-} a h$ Advisory Council of Bursa Malaysia has yet to issue any resolution on its permissibility.

\section{Bursa Malaysia Securities Berhad}

\section{Sharī ah and legal issues affecting contra trading}

This paper analyzes and discusses seven issues that are found in the practice of contra trading at Bursa Malaysia. The issues relate to:

(1) the shares' ownership before the Settlement Day;

(2) whether the contra transaction is a pseudo or real sale of asset;

(3) the possession of the sold shares (qabd al-mabī - قبض المبيع) and transfer of liability (intiqāintiqāl al-damān - انتقال الضمان);

(4) deferment of both counter-values ( $t a^{\prime}$ jùl al-badalayn - تأجيل البدلين);

(5) selling something before taking it into possession (bay al-shay' qabla qabdihi (بيع الثيء قبل فبضه ;

(6) profiting without bearing liability (ribhu ma lam yadman - ربح مالم يضمن فيضع)); and

(7) gambling (muqāmarah/maysir - المقامرة/الميسر).

The discussion of the first issue is based on the question of whether, at the time the buyer enters into the contra trading, he is already the real owner of the shares and thus entitled to sell them. From the Shari' ah perspective, for the shares to be transferred and owned by the buyer, the transaction that is evidenced by the Contract Note must fulfil the requirements of a valid contract. The underlying principle is that ownership of the subject matter of a sale is transferred to the buyer upon the conclusion of a sale contract regardless of whether the subject of sale has been delivered to the buyer or the price has been paid to the seller (al-Mawsü'ah al-Kuwaytiyyah, 9/36). The discussion of the issue of ownership refers also to the position of the law that raises some predicament with respect to the limitation of the right of the buyer over the shares.

The second issue deals with the legal-Shari'ah conundrum about the status of the buyer/ contra trader as the owner of the shares during the onward sale. The law clearly stipulates that true and ultimate beneficial ownership is with the person in whose name the shares are duly registered with the Central Depository. This paper is, however, of the view that from the Shari' ah perspective the contra trader is the real owner of the shares that he onward sells to a third party. The purchase transaction done by the contra trader fulfils all the pillars and conditions of a valid sale and purchase transaction.

On the issue of possession, this paper is of the view that shares represent one's ownership of the capital of the company and the rights associated with it; thus, owning shares can never entail physical possession. Therefore, in the case of buying and selling of shares, the possession involved is argued to be constructive possession. The question that follows this proposition is whether the purchaser has constructively taken the shares into his possession on the transaction day, i.e. $\mathrm{T}+0$. In general, constructive possession is attained by removing impediments to the buyer accessing the commodity (takhliah) and enabling him to deal with it as he wills (tamkin). Therefore, the liability for loss of the asset will transfer to the person who has taken the asset into his constructive possession (Islamic Finance 
$\mathrm{IJIF}$

9,2

Knowledge Repository, 2017). Based on this, the paper argues that "takhliah" and "tamkin" as mentioned by jurists for constructive possession are not fulfilled before the delivery of the shares on $\mathrm{T}+3$, as the buyer has not been given access to the shares or any power over them, except the buyer's ability to sell them. A mere legal right to sell the shares and to gain profit from the sale does not suffice to constitute constructive possession for the buyer when the benefits and liabilities of the asset (i.e. the underlying company) are still vested with the original seller. Additionally, the paper argues that being legally allowed to sell an asset and being liable to its price movement does not at all mean that the liability of the asset has actually transferred to the buyer.

The fourth issue on the deferment of both counter-values ( $t a^{\prime} j \bar{l} l$ al-badalayn) involves the discussion of gharar (uncertainty) due to the non-delivery of counter-values in the contract session. The question that is asked is whether contra trading involves the element of $t a^{\prime} j \bar{l} l a l$ badalayn. The paper is of the view that in ta'jl al-badalayn the issue is not about when the transaction takes place but, rather, about when the subject matter is delivered and the price is settled. This will only happen and appear in the accounts of both parties three days after the transaction. Thus, the three-day delay for the delivery of both counter-values could be evidence for the conclusion that share trading does involve $t a^{\prime} j \bar{l} l$ al-badalayn. However, the paper takes the view of the Mālikī School that the three-day deferment can be deemed as minor and tolerable (Ibn Rushd, 1988, 2:28). In addition, the three-day deferment in shares trading has been accepted as the international industry convention ('urf ahl al-șana' $a h$ ). That could constitute a strong basis of need (hajjah) that justifies a relaxation of the general prohibition of $t a^{\prime}$ jill al-badalayn.

On the fifth issue, selling something before taking it into possession, the discussion turns on whether shares are considered a food item. Obviously, they are not. If so, shares would fall outside the prohibition of selling food before taking it into one's possession.

The sixth issue deals with Prophet Muhammad's ( $\left.\begin{array}{c}\text { (c) } \\ \text { ald }\end{array}\right)$ prohibition on taking profit from something for which one does not bear liability (al-Nasā $\overline{1}, 1986)$. The question that leads the discussion is whether the buyer is entitled to the profit made from the contra trading (prior to taking possession of such shares and when the buyer has yet to bear any liability for them). Despite the practice in the market that allows the contra traders to profit, the paper finds reason to question this norm due to the governing trading law and the cash settlement procedures. In the event of failure to deliver the shares, the rights, entitlements and liabilities are accorded based on the owners' names registered in the shares registration record. The buyer (contra trader) is not a registered shareholder/beneficial owner of the shares; thus, he will not be able to benefit from the rights and entitlements arising from the shares nor be liable for the liabilities arising from them. Therefore, making profit from contra trading is viewed as prohibited.

The discussion on the last Shari'ah issue, gambling, is based on the resolution of the Accounting and Auditing Organization for Islamic Financial Institutions (AAOIFI) Shari' ah standard no. 21 on financial papers that allows for speculative trades (AAOIFI, 2015). The paper further argues that contra trading is not between two parties betting on a same bet, which will end up with one of them winning and the other losing. Instead contra trading is about selling an asset at the market price, whereas the other party may want to keep the shares for a long investment because the price may keep on increasing.

\section{Research findings}

This paper finds that contra trading involves a real sale and purchase of shares. It further finds that from the Shari'ah perspective, irrespective of the legal requirement for the share's legal ownership, at the time when the contra trade is executed, the contra trader is the real 
owner of the shares that he onward sells to a third party. The reason is that the purchase transaction done by the contra trader fulfils all the pillars and conditions of a valid sale and purchase transaction.

With regards to the issue of delivery and possession of shares as well as the transfer of liability of shares during the onward sale, contrary to the stance of AAOIFI, this paper finds that the shares have not been taken into the possession of the contra trader, either physically or constructively. This paper further finds that the liability associated with the shares has not been transferred to the contra trader.

On the issue of deferment of both counter-values, which many scholars as well as AAOIFI do not allow, this paper finds that it is not a fundamental issue in Shari'ah. It is further viewed that the deferment of three days can be considered as minor, hence tolerable. Related to this issue is the question of possession and transfer of liability in the sale of shares before possession. Based on the views of many Muslim scholars that allow selling before possessing the sold item so long as the item is not food, the paper concludes that selling shares before the buyer possesses them is allowed.

In relation to the issue of profiting without bearing liability, the paper finds this practice

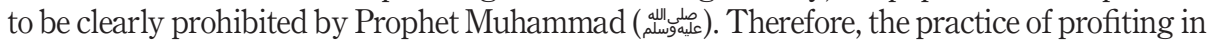
the contra trading, when the shares are yet to be in the buyer's possession and when liability of the shares has yet to be transferred to him, transgresses this prohibition. Having said that, this paper argues that the permissibility of contra trading could still be argued from the contextual approach of public interest (ma șlahah) and need ( $h \bar{a} j a h)$.

Finally, the paper concludes that there is no element of gambling in contra trading. Gambling allows one party to gain at the expense of the other, and this is not so in the case of contra trading. In contra trading, the broker will always make a profit from the brokerage fee and not the price movement, i.e. the chargeable fee when a trader purchases shares and executes a contra trade, regardless of whether the onward sale is profitable or bears a loss. The sale itself could also be profitable to all the sellers, including the original seller and the onward sellers (contra traders), if the price of the shares keeps on increasing and also to the ultimate buyer who decides to keep the shares and does not onward sell them. If the price decreases and the contra trader makes a loss, it does not amount to gambling either, as it is a normal risk that any trader has to take.

\section{Conclusion and recommendations}

The paper has deliberated in length the issues of contra trading, analyzing them from the angles of Shari'ah and common law. The findings of the paper reveal that there are some identified issues in contra trading that require future in-depth deliberation. On that basis, the paper makes two recommendations.

First, it recommends a change in the formula of cash settlement for failed contracts. Currently, the liability for any failure in delivering the shares is solely borne by the original seller to the ultimate buyer. The onward sellers (in between the original seller and the ultimate buyer) will not bear any of these compensations and charges, and they are allowed to keep the profits that they have received. Therefore, to address the prohibition of profiting without bearing any liability, the paper proposes that in the case of default in delivery, all sellers including the original seller and the subsequent onward sellers shall collectively pay the compensation and charges to the ultimate buyer in proportion to their earned profit.

Second, the paper recommends that further empirical and quantitative studies be carried out in future for the purpose of ascertaining the extent of the public need for contra trading and the real benefits that contra trading brings to the society. These studies would serve as 
indicators of whether contra trading deserves a relaxation from the strict Sharīah ruling and, on that basis, be considered permissible.

\section{References}

AAOIFI (2015), Sharīah Standards for Islamic Financial Institutions (English version), Accounting and Auditing Organization for Islamic Financial Institutions, Manama.

Al-Nasā '̄ (1986), Al-Sunan Al-Sughra, 3rd ed., Maktab al-Mațbū'āt al- 'Islāmiyyah, Halab.

Ibn Rushd, A.A.W. (1988), Al-Muqaddimāt Al-Mumahhidāt, Dar al-Gharb al-Islāmi, Beirut.

Islamic Finance Knowledge Repository (I-fikr) (2017), "Possession: its different forms, especially the modern forms and their rules", The Council of the Islamic Fiqh Academy, in its Sixth Session held in Jeddah, Kingdom of Saudi Arabia, from 17-23 Sha'baan, 1410H (corresponding to 14-20 March 1990), available at: http://ifikr.isra.my/fatwa/final_level2/ICM0903/5943 (accessed 24 August 2017).

\section{Further reading}

Al-Mawsū'ah al-Fiqhiyyah al-Kuwaitiyyah (1427AD), 1st ed, Maḍābi` Dār al-Ṣafwah.

\section{About the authors}

Noor Suhaida Kasri, $\mathrm{PhD}$, is a Researcher cum Head of the Islamic Capital Market Unit at the International Shari'ah Research Academy for Islamic Finance (ISRA). She obtained a Doctor of Philosophy in Islamic Banking Finance and Management from the University of Gloucestershire, UK, and Master in Laws from King's College of London. Noor Suhaida Kasri is the corresponding author and can be contacted at: noor@isra.my

Burhanuddin Lukman is a Researcher cum Head of the Takaful Unit at ISRA. He holds a bachelor's degree in Shari'ah from Islamic University of Medina, Saudi Arabia, and a master's degree in Figh and Usul al-Fiqh from Al Bayt University, Jordan.

For instructions on how to order reprints of this article, please visit our website: 